\title{
Pengaruh Usia, Pendidikan, dan Pengetahuan Terhadap Konsumsi Tablet Tambah Darah pada Ibu Hamil di Puskesmas Maron, Kabupaten Probolinggo
}

\section{The Influence of Age, Education, and Knowledge of Consumption of Iron Tablets on Pregnant Women in Maron Public Health Center, District of Probolinggo}

\author{
Fauziah Itsnaini Shofiana*, Denok Widari ${ }^{1}$, Sri Sumarmi ${ }^{2}$
}

\begin{abstract}
ABSTRAK
Latar Belakang: Anemia merupakan masalah gizi utama di Indonesia, salah satunya terjadi pada ibu hamil. Oleh karena itu pemerintah mengeluarkan program pencegahan dan pengendalian anemia defisiensi besi melalui suplementasi besi berturut-turut selama setidaknya 90 hari selama kehamilan. Tujuan: Tujuan penelitian ini untuk menganalisis pengaruh usia, pendidikan, dan pengetahuan terhadap konsumsi tablet tambah darah.

Metode: Penelitian ini dilakukan di Puskesmas Maron, Kabupaten Probolinggo menggunakan desain cross sectional, sampel sebanyak 40 ibu hamil TM III yang mendapatkan 90 tablet besi dengan teknik simple random sampling. Pengaruh usia, pendidikan, dan pengetahuan dianalisis menggunakan uji regresi logistik dengan nilai signifikansi $<0,05$.

Hasil: Hasil penelitian menunjukkan bahwa pengetahuan ibu hamil berpengaruh terhadap konsumsi tablet besi $(p=0.026)$, tapi usia $(p=0.914)$, pendidikan $(p=0.419)$ tidak berpengaruh terhadap konsumsi tablet besi.

Kesimpulan: Konsumsi tablet besi pada ibu hamil dipengaruhi oleh pengetahuan ibu hamil. Rendahnya pengetahuan ibu, maka akan tingkat konsumsi tablet tambah darah semakin rendah.
\end{abstract}

Kata Kunci: konsumsi tablet tambah darah, usia, pendidikan, pengetahuan ibu hamil

\section{ABSTRACT}

Background: Anemia is a major nutritional problem in Indonesian, one of the occurs in pregnant women. Therefore the government issued prevention and control program of iron deficiency anemia through consecutive iron supplementation for at least 90 days during pregnancy.

Objectives: This study aimed to analyze the influence of age, education and knowledge of consumption of iron tablets.

Methods: This research was conducted in Maron Public Health Center, District of Probolinggo using a cross sectional design. A sample of 40 pregnant women in their last trimester who have received 90 iron tablets was recruited with a simple random sampling technique. The influence of age, education, and knowledge was analyzed using logistic regression test with significance value $<0,05$.

Results: The results showed that the knowledge of pregnant women affected of consumption of iron tablets $(p=0.026)$, but age $(p=0.914)$, education $(p=0.419)$ did not affected of consumption of iron tablets.

Conclusion: The conclusion of this research is that consumption of iron tablets in pregnant women is influenced by knowledge of pregnant women. The lack knowledge of the mother, the lower the level consumption of iron tablets. 
Keywords: consumption of iron tablets, age, education, knowledge of pregnant women

\author{
*Koresponden: \\ fauziahitsnainishofiana17@gmail.com \\ ${ }^{1}$ Dinas Kesehatan Kota Surabaya \\ ${ }^{2}$ Departemen Gizi Kesehatan, Fakultas Kesehatan Masyarakat, Universitas Airlangga
}

\section{PENDAHULUAN}

Anemia dianggap menjadi faktor terpenting peningkatan beban penyakit di seluruh dunia. Ibu hamil kelompok yang rentan terkena masalah anemia ${ }^{1}$. Anemia gizi besi timbul disebabkan karena kekurangan zat besi yang mengakibatkan proses pembentukan sel darah merah terganggu². Tingginya prevalensi anemia disebabkan kurangnya asupan zat besi, rendahnya absorpsi zat besi, pendarahan, penyakit malaria, infeksi cacing maupun infeksi lainnya ${ }^{2}$. Program pemberian tablet tambah darah untuk ibu hamil minimal 90 butir selama masa kehamilan merupakan salah bentuk mengatasi masalah anemia yang dirancang oleh pemerintah di Indonesia ${ }^{3}$. Setiap tablet tambah darah mengandung zat besi yang setara dengan $60 \mathrm{mg}$ besi elemental dalam bentuk Ferro Sulfat, Ferro Fumarat atau Ferro Gluconat dan Asam Folat sebesar 0,400 mg . Dengan mengkonsumsi tablet rutin setiap hari dapat mengurangi prevalensi anemia dan mencegah terjadinya anemia pada ibu hamil ${ }^{4}$.

Saat melakukan kegiatan antenatal, tenaga kesehatan diharuskan memberikan pelayanan yang terbaik salah satunya dengan pemberian tablet tambah darah minimal 90 butir selama masa kehamilan diberikan sejak kunjungan pertama ${ }^{5}$. Menurut data pemerintah, rata-rata cakupan tablet $\mathrm{Fe}-3$ secara Nasional sebesar $85,1 \%$ dan rata-rata cakupan tablet Fe-3 di Provinsi Jawa Timur sebesar 84,9\% ${ }^{6}$. Di Kabupaten Probolinggo tahun 2015, cakupan Fe-3 mencapai (90,3\%) atau terdapat 3.730 ibu hamil yang mendapatkan $\mathrm{Fe}-3^{7}$.

Probolinggo merupakan salah satu Kabupaten di Provinsi Jawa Timur memiliki prevalensi anemia pada wanita usia subur $67 \%^{8}$. Sebesar $48,5 \%$ pengantin baru wanita di Kabupaten Probolinggo mengalami masalah anemia ${ }^{9}$. Studi baru menunjukkan proporsi anemia wanita yang sudah menikah di
Kabupaten Probolinggo adalah $15 \%{ }^{10}$. Ibu hamil yang mengkonsumsi tablet secara rutin sebagai ketaatan ibu hamil mengkonsumsi tablet besi selama kehamilan sesuai dengan anjuran petugas kesehatan. Rendahnya ibu hamil dalam mengkonsumsi TTD disebabkan berbagai faktor, yaitu faktor lupa, takut bayi menjadi besar, kurangnya kesadaran terkait dengan pentingnya mengkonsumsi tablet dan dampak pada ibu serta janin jika ibu tidak mengkonsumsi tablet secara rutin, serta timbulnya efek samping, seperti mual dan pusing yang ditimbulkan setelah mengkonsumsi tablet ${ }^{1}$.

Penelitian sebelumnya menjelaskan bahwa ibu hamil yang mengkonsumsi tablet $\geq$ 90 butir selama kehamilan mempunyai risiko mengalami masalah anemia lebih rendah daripada ibu hamil yang hanya mengkonsumsi tablet $\leq 90$ butir selama kehamilan ${ }^{11}$. Perempuan di Indonesia dengan rentang usia 10-59 tahun yang telah mendapatkan tablet sebesar 19,3\% tidak mengkonsumsi tablet ,sedangkan yang mengkonsumsi tablet 90 hari sebesar $18 \%^{12}$. Konsumsi tablet tinggi ataupun rendah ditentukan rasa mual dan bau dari tablet walaupun ibu hamil memasuki usia kehamilan TM $3^{13}$. Tidak rutin mengkonsumsi tablet setiap hari dikarenakan timbulnya rasa bosan yang mengakibatkan ibu hamil malas dan lupa untuk mengkonsumsi tablet ${ }^{13}$.

Penelitian sebelumnya menjelaskan bahwa rendahnya ibu hamil mengkonsumsi tablet di Puskesmas Seberang Padang dapat disebabkan karena masih banyak ibu hamil yang memiliki pengetahuan kurang mengenai zat besi ${ }^{14}$. Akibatnya, kesadaran ibu hamil untuk mengkonsumsi tablet tambah darah juga masih rendah. Pengetahuan mengenai kebutuhan zat besi, manfaat pada zat besi, sumber makanan mengandung zat besi, akibat yang ditimbulkan apabila kekurangan zat besi, dan informasi lainnya dapat diperoleh ibu melalui penyuluhan yang diberikan petugas 
kesehatan dalam kunjungan ANC. Penelitian sebelumnya juga menjelaskan adanya hubungan pendidikan ibu hamil dengan perilaku ibu hamil dalam mengkosumsi tablet tambah darah ${ }^{15}$. Sebesar 6,608 kali ibu hamil yang berpendidikan tinggi akan patuh daripada ibu hamil berpendidikan rendah ${ }^{16}$. Penelitian dilakukan di Desa Kotaraja, Kecamatan Sikur, Kabupaten Lombok menunjukkan bahwa ibu hamil dalam mengkonsumsi TTD hanya sebesar $40 \%{ }^{17}$.

Berdasarkan uraian tersebut tujuan dari penelitian ini untuk menganalisis pengaruh usia, pendidikan, dan pengetahuan terhadap konsumsi tablet tambah darah pada ibu hamil di Puskesmas Maron Kabupaten Probolinggo.

\section{METODE}

Jenis penelitian ini menggunakan observasional analitik dan desain penelitian cross sectional dilakukan di Puskesmas Maron Kabupaten Probolinggo. Puskesmas Maron dipilih sebagai tempat penelitian karena lokasi tersebut merupakan salah satu wilayah yang paling banyak terdapat ibu hamil di Kabupaten Probolinggo ${ }^{18}$. Ibu hamil dipilih sebagai responden karena salah satu kelompok rentan mengalami masalah gizi terutama anemia. Penelitian ini menggunakan populasi semua ibu hamil TM III yang berkunjung dan telah mendapatkan tablet 90 butir di Puskesmas Maron, Kabupaten Probolinggo dengan jumlah 129 ibu hamil. Sebanyak 40 ibu hamil sebagai sampel dalam penelitian yang menggunakan teknik simple random sampling dihitung menggunakan rumus Lemeshow, telah memenuhi kriteria inklusi, yaitu ibu hamil TM III yang berkunjung dan menerima TTD 90 butir di Puskesmas Maron Kabupaten Probolinggo.

Variabel indipenden meliputi usia ibu hamil memiliki klasifikasi, yaitu usia $<20$ tahun, 20-35 tahun, dan > 35 tahun, menggunakan skala data ordinal ${ }^{19,20}$. Variabel pendidikan ibu hamil memiliki klasifikasi, yaitu tidak tamat SD, tamat SD, tidak tamat SMP, tamat SMP, tidak tamat SMA, tamat SMA, dan perguruan tinggi, menggunakan skala data ordinal. Variabel pengetahuan ibu hamil dengan klasifikasi, yaitu kurang (skor < 55), sedang (skor 56-79), dan baik (skor>79), menggunakan skala data ordinal. Pengetahuan ibu hamil terkait dengan anemia dan tablet tambah darah terdiri 5 pertanyaan tertutup. Pertanyaan pengetahuan terkait anemia sebanyak 3 pertanyaan dengan rincian pertanyaan apa yang menyebabkan anemia pada ibu hamil?, apa bahaya anemia pada ibu hamil?, apa bahaya pada bayi yang dikandung? dan pengetahuan terkait tablet tambah darah sebanyak 2 pertanyaan dengan rincian pertanyaan apa manfaat ibu hamil jika mengkonsumsi tablet tambah darah?, dan bagaimana cara mengkonsumsi tablet tambah darah dengan benar?. Kuesioner pengetahuan ini mengadopsi dari penelitian sebelumnya yang telah dilakukan uji validitas dan reliabititas kuesioner menggunakan Chornbach's Alpha ${ }^{21}$. Variabel dependen meliputi konsumsi tablet tambah darah dengan klasifikasi, yaitu tidak diminum jika ibu hamil tidak mengkonsumsi tablet yang diberikan, minum tidak rutin jika ibu tidak rutin setiap hari mengkonsumsi tablet yang diberikan, minum rutin jika ibu rutin setiap hari mengkonsumsi tablet yang diberikan menggunakan skala data ordinal. Variabelvariabel tersebut tercantum dalam kuesioner dengan menggunakan metode wawancara pada ibu hamil.

Data penelitian yang diperoleh dari lapangan, data mentah yang akan diolah dan dihitung menggunakan tabel distribusi frekuensi dan tabel silang. Uji statistik menggunakan uji regresi logistik, tingkat signifikansi $0,05 \quad(p<0,05)$ untuk mengetahui pengaruh usia, pendidikan, dan pengetahuan ibu hamil terhadap konsumsi tablet tambah darah. Hasil penelitian menunjukkan bahwa ada pengaruh pengetahuan terhadap konsumsi tablet tambah darah dengan nilai $\alpha=$ 0,05 .

Penelitian ini telah dilakukan uji etik dan juga mendapatkan izin dari Komisi Etik Fakultas Kesehatan Masyarakat Universitas Airlangga Surabaya dengan sertifikat Nomor 496-KEPK.

\section{HASIL DAN PEMBAHASAN}

Distribusi frekuensi ibu hamil menurut usia, pendidikan, dan pengetahuan disajikan dalam Tabel 1. Mayoritas ibu hamil berusia 2035 tahun sebesar $72,5 \%$ dengan mayoritas pendidikan ibu hamil tamat SD/sederajat dan tamat SMA/sederajat masing-masing sebesar 
$30 \%$. Kategori pengetahuan kurang (skor $<55$ ) yang paling dominan dengan persentase sebesar $50 \%$. Ibu hamil dominan memiliki tingkat konsumsi tablet tambah darah yang tidak rutin. Sebanyak $67,5 \%$ reponden tingkat konsumsi tablet tambah darah yang tidak rutin dan hanya $32,5 \%$ responden rutin setiap hari mengkonsumsi

Tabel 1. Distribusi Frekuensi Ibu Hamil Menurut Usia, Pendidikan, dan Pengetahuan

\begin{tabular}{lcc}
\hline \multicolumn{1}{c}{ Variabel } & $\begin{array}{c}\text { Jumlah } \\
(\mathbf{n})=\mathbf{4 0}\end{array}$ & $\begin{array}{c}\text { Persentase } \\
\text { (\%) }\end{array}$ \\
\hline $\begin{array}{l}\text { Usia Ibu Hamil } \\
<20 \text { tahun }\end{array}$ & 5 & 12,5 \\
20-35 tahun & 29 & 72,5 \\
$>35$ tahun & 6 & 15 \\
\hline $\begin{array}{l}\text { Pendidikan Ibu } \\
\text { Hamil }\end{array}$ & 3 & 7,5 \\
$\quad$ Tidak Tamat SD & 12 & 30 \\
Tamat SD & 10 & 25 \\
Tamat SMP & 12 & 30 \\
Tamat SMA & 3 & 7,5 \\
$\quad$ Perguruan Tinggi & & \\
\hline $\begin{array}{l}\text { Pengetahuan Ibu } \\
\text { Hamil }\end{array}$ & & \\
Kurang (skor $<$ & 11 & 27,5 \\
55) & 9 & 22,5 \\
Sedang (skor 56- & & \\
79) & & \\
Baik (skor $>79)$ & & \\
\hline
\end{tabular}

Tabel 2. Distribusi Konsumsi Tablet Tambah Darah Pada Ibu Hamil

\begin{tabular}{lcc}
\hline Konsumsi TTD & $\begin{array}{c}\text { Jumlah } \\
(\mathbf{n})=\mathbf{4 0}\end{array}$ & $\begin{array}{c}\text { Persentase } \\
(\mathbf{\%})\end{array}$ \\
\hline $\begin{array}{l}\text { Minum tidak } \\
\text { rutin }\end{array}$ & 27 & 67,5 \\
\hline Minum rutin & 13 & 32,5 \\
\hline
\end{tabular}

tablet tambah darah. Penelitian ini sejalan dengan penelitian sebelumnya yang menyatakan sebanyak responden (58,9\%) tidak patuh mengkonsumsi tablet tambah darah $^{22}$.

Usia ibu untuk masa kehamilan dan bersalinan yang baik pada usia 20-35 tahun. Ibu hamil memiliki risiko atau tidak dalam kehamilan dengan cara jika ibu hamil mengandung di usia $<20$ tahun dan $>35$ tahun termasuk dalam usia berisiko tinggi ketika melahirkan, sedangkan usia tidak berisiko jika ibu hamil rentang usia 20-35 tahun ${ }^{5}$. Ibu hamil dengan usia $<20$ tahun yang mengkonsumsi tablet tambah darah rutin setiap hari hanya $20 \%$, ibu hamil usia 20-35 tahun mengkonsumsi tablet tambah darah secara rutin setiap hari sebesar $37,9 \%$, ibu hamil usia $>35$ tahun yang mengkonsumsi tablet tambah darah rutin sebesar $16,7 \%$, sedangkan ibu hamil tidak mengkonsumsi tablet secara rutin dominan pada usia 20-35 tahun sebesar $62,1 \%$ (Tabel 3). Hasil analisis menunjukkan tidak ada pengaruh usia ibu terhadap konsumsi tablet ( $p$ $=0,914>0,05)$ terhadap konsumsi tablet tambah darah (Tabel 4). Hasil penelitian ini sama dengan penelitian dahulu yang menjelaskan bahwa tidak ada pengaruh usia terhadap konsumsi tablet ${ }^{23,15,24}$. Ibu hamil yang memiliki usia lebih tua belum tentu memiliki tingkat konsumsi tablet tinggi, begitu pula sebaliknya ibu hamil yang berusia lebih muda belum tentu memiliki tingkat konsumsi tablet yang rendah.

Pada ibu hamil di wilayah Puskesmas Maron, usia bukanlah variabel yang berpengaruh terhadap konsumsi tablet tambah darah. Ibu hamil berusia lebih tua belum tentu memiliki tingkat konsumsi tablet tambah darah tinggi, namun sebaliknya ibu hamil berusia lebih muda juga belum tentu memiliki tingkat konsumsi tablet tambah darah rendah. Ibu hamil tidak mengetahui kelompok usia berisiko dan tidak berisiko untuk hamil, sehingga tidak mengetahui bagaimana kebutuhan konsumsi tablet, khususnya pada ibu hamil pada kelompok usia berisiko. Ibu hamil menganggap usia dan kehamilan tidak berkaitan, padahal ketika ibu hamil berada usia risiko tinggi kemungkinan adanya komplikasi kehamilan dan akan menimbulkan risiko yang lebih besar daripada ibu hamil yang tidak pada usia berisiko.

Pendidikan dapat meningkatkan pengetahuan yang akan meningkatkan konsumsi tablet serta mengurangi risiko buruk bagi kesehatan ibu dan anak ${ }^{25}$. Berdasarkan Tabel 3, ibu hamil dengan pendidikan SD yang mengkonsumsi tablet secara rutin sebesar $50 \%$. Ibu hamil tamat SMP yang mengkonsumsi tablet secara rutin sebesar $10 \%$. 
Tabel 3. Tabel Silang Usia, Pendidikan, dan Pengetahuan Pada Konsumsi Tablet Tambah Darah

\begin{tabular}{lccc}
\hline \multicolumn{1}{c}{ Variabel } & \multicolumn{2}{c}{ Konsumsi Tablet Tambah Darah } & \multirow{2}{*}{ Jumlah } \\
\cline { 2 - 3 } & $\begin{array}{c}\text { Minum Tidak Rutin } \\
\mathbf{n}(\%)\end{array}$ & $\begin{array}{c}\text { Minum Rutin } \\
\mathbf{n}(\%)\end{array}$ & \\
\hline Usia Ibu Hamil & & & \\
$<20$ tahun & $4(80 \%)$ & $1(20 \%)$ & $5(100 \%)$ \\
$20-35$ tahun & $18(62,1 \%)$ & $11(37,9 \%)$ & $29(100 \%)$ \\
$>35$ tahun & $5(83,3 \%)$ & $1(16,7 \%)$ & $6(100 \%)$ \\
\hline Pendidikan Ibu Hamil & $3(100 \%)$ & & \\
Tidak tamat SD & $6(50 \%)$ & $0(0 \%)$ & $3(100 \%)$ \\
Tamat SD & $9(90 \%)$ & $6(50 \%)$ & $12(100 \%)$ \\
Tamat SMP & $8(66,7 \%)$ & $1(10 \%)$ & $10(100 \%)$ \\
Tamat SMA & $1(33,3 \%)$ & $4(33,3 \%)$ & $12(100 \%)$ \\
Perguruan Tinggi & $2(66,7 \%)$ & $3(100 \%)$ \\
\hline Pengetahuan Ibu Hamil & $16(80 \%)$ & & \\
Kurang (skor < 55) & $8(72,7 \%)$ & $4(20 \%)$ & $20(100 \%)$ \\
Sedang (skor 56-79) & $3(33,3 \%)$ & $3(27,3 \%)$ & $22(100 \%)$ \\
Baik (skor > 79) & & $6(66,7 \%)$ & $9(100 \%)$ \\
\hline
\end{tabular}

Ibu hamil dengan pendidikan tamat SMA mengkonsumsi tablet secara rutin sebesar $33,3 \%$ dan ibu hamil mencapai perguruan tinggi mengkonsumsi tablet secara rutin sebesar $66,7 \%$. Ibu hamil yang tidak mengkonsumsi tablet secara rutin dominan pada tamat SMP sebesar $90 \%$. Hasil analisis menunjukkan tidak ada pengaruh variabel pendidikan ibu terhadap konsumsi tablet $(p=$ $0,419>0,05)$ terhadap konsumsi tablet tambah darah (Tabel 4).

Tabel 4. Pengaruh Usia, Pendidikan, dan Pengetahuan Terhadap Konsumsi Tablet Tambah Darah

\begin{tabular}{cccc}
\hline Variabel & $\boldsymbol{\beta}$ & $\begin{array}{c}\boldsymbol{p}- \\
\text { value }\end{array}$ & $\begin{array}{c}\text { OR } \\
\text { (Exp } \\
\text { (B)) }\end{array}$ \\
\hline $\begin{array}{l}\text { Usia Ibu Hamil } \\
\text { Pengetahuan } \\
\text { Ibu Hamil }\end{array}$ & 0,024 & 0,914 & - \\
$\begin{array}{c}\text { Pendidikan Ibu } \\
\text { Hamil }\end{array}$ & $-0,176$ & 0,026 & 2,720 \\
\hline
\end{tabular}

Hasil penelitian ini sama dengan penelitian dahulu menjelaskan tidak ada pengaruh signifikan pendidikan ibu hamil terhadap konsumsi tablet ${ }^{26,27,28}$. Dari 7 tingkat pendidikan, konsumsi tablet tambah darah terbanyak masing-masing ada pada konsumsi tablet tambah darah tidak rutin. Hal ini menunjukkan pendidikan ibu tidak ada pengaruh terhadap konsumsi tablet tambah darah, bukan berarti jika pendidikan yang tinggi maka akan mengkonsumsi tablet tambah darah secara rutin, begitu pula sebaliknya apabila pendidikan yang rendah, maka bukan berarti rutin mengkonsumsi tablet ataupun tidak rutin mengkonsumsi tablet. Pengalaman yang banyak pada ibu hamil, memiliki tingkat kematangan jiwa serta emosi dalam mengambil suatu keputusan dalam mengkonsumsi tablet setiap hari secara rutin. Pendidikan seseorang dapat mempengaruhi pemahaman atas suatu prosedur, maka semakin tinggi pendidikan ibu, makin semakin banyak informasi dan pengetahuan dimiliki sehingga kepatuhan semakin tinggi ${ }^{29}$.

Dari 7 tingkat pendidikan, konsumsi tablet tambah darah terbanyak masing-masing ada pada konsumsi tablet tidak rutin. Hal ini menunjukkan bahwa pendidikan seseorang tidak ada pengaruh terhadap konsumsi tablet, bukan berarti apabila pendidikan yang tinggi maka akan mengkonsumsi tablet secara rutin, namun sebaliknya pendidikan rendah maka bukan berarti mengkonsumsi tablet secara tidak rutin. Apabila ibu hamil memiliki lebih banyak pengalaman serta terkait dengan kesehatan, dan memiliki kematangan jiwa serta emosi dalam mengambil keputusan untuk mengkonsumsi tablet setiap hari. Ibu hamil tidak hanya mendapat informasi terkait kehamilan dari bangku sekolah, namun juga 
dari berbagai sumber salah satunya saat kunjungan kehamilan di Puskesmas, kelas ibu hamil ataupun saat Posyandu. Pada tingkat pendidikan memiliki pengetahuan yang baik untuk mempersiapkan segala sesuatu yang berkaitan dengan kesehatannya.

Tingkat pendidikan tinggi akan memiliki pengetahuan yang baik pula $^{30}$ terutama mengenai perawatan tentang kehamilan, asupan gizi saat hamil, mencegah penyakit serta sikap menuju persalinan. Tabel 3, ibu hamil dengan pengetahuan kurang (skor $<55$ ) yang mengkonsumsi TTD secara rutin sebesar $20 \%$. Ibu hamil dengan pengetahuan sedang (skor 56-79) yang mengkonsumsi TTD secara rutin sebesar $27,3 \%$. Ibu hamil dengan pengetahuan baik (skor > 79) yang mengkonsumsi TTD secara rutin sebesar $66,7 \%$. Ibu hamil yang tidak mengkonsumsi TTD secara rutin dominan pada pendidikan kurang sebesar $80 \%$ sebanyak 16 ibu hamil.

Berdasarkan hasil uji statistikt pada Tabel 4, didapatkan hasil $(p=0,026<0,05)$ sehingga ada pengaruh yang signifikan variabel pengetahuan terhadap konsumsi tablet tambah darah ibu hamil di Puskesmas Maron Kabupaten Probolinggo. Dari hasil analisis didapatkan ibu hamil memiliki pengetahuan kurang kemungkinan untuk tidak rutin mengkonsumsi tablet sebesar 2,720 kali dibandingkan dengan ibu hamil memiliki pengetahuan baik. Pada penelitian didukung penelitian sebelumnya, menyatakan bahwa pengetahuan ibu dapat mempengaruhi konsumsi tablet tambah darah ${ }^{21,13,31}$. Ibu hamil dengan pengetahuan baik, akan cenderung mengkonsumsi tablet tambah darah rutin dibandingkan dengan ibu hamil memiliki pengetahuan kurang dalam mengkonsumsi tablet tambah darah untuk pencegahan anemia $^{16,32,33,34}$.

Penelitian sebelumnya juga mengatakan bahwa terdapat hubungan pengetahuan ibu hamil dengan kepatuhan konsumsi tablet ${ }^{24,28,15}$. Tingkat konsumsi tablet pada ibu hamil dipengaruhi pengetahuan mengenai manfaat serta dampak yang ditimbulkan dari masalah anemia ${ }^{35}$. Pengetahuan memiliki peran penting dalam menentukan tingkat konsumsi tablet pada ibu hamil karena akan berpengaruh langsung pada sikap ibu hamil untuk mengonsumsi tablet setiap hari ${ }^{35}$.
Pengetahuan kurang mengenai masalah anemia pada ibu hamil akan berpengaruh terhadap perilaku kesehatan pada saat hamil yang mengakibatkan kurang optimal untuk melakukan perilaku pencegahan terkena masalah anemia kehamilan ${ }^{36}$.

Dalam pelaksanaan penelitian ini, terdapat keterbatasan pada pengambilan data terdapat responden yang baru melakukan kehamilan di tempat penelitian yang sebelumnya tinggal dan melakukan pemeriksaan di luar negeri serta responden tersebut tidak membawa buku pemeriksaan kehamilan ditempat sebelumnya. Sehingga peneliti merasa kesulitan untuk mengkaji tablet yang telah diterima dan dikonsumsi ibu hamil.

\section{KESIMPULAN}

Pengetahuan ibu hamil berpengaruh terhadap konsumsi tablet tambah darah di Puskesmas Maron Kabupaten Probolinggo. Hasil penelitian menjelaskan semakin rendah pengetahuan ibu hamil, maka setiap hari tidak rutin ataupun semakin rendah dalam mengkonsumsi tablet tambah darah. Usia dan pendidikan ibu hamil tidak memiliki pengaruh terhadap konsumsi tablet tambah darah.

\section{ACKNOWLEDGEMENT}

Penulis mengucapkan terima kasih seluruh responden ibu hamil, para kader di setiap posyandu, serta tenaga kesehatan di Puskesmas Maron dan juga semua staff pengajar program Studi S1 Gizi Fakultas Kesehatan Masyarakat Universitas Airlangga.

\section{REFERENSI}

1. World Health Organization. Anaemia Policy Brief. (2014).

2. Adriani, M; Wirjatmadi, B. Pengantar Gizi Masyarakat. (Kencana Prenada Media Group, 2014).

3. Kementerian Kesehatan RI. Peraturan Menteri Kesehatan Republik Indonesia Nomor 88 Tahun 2014. (2014).

4. Purnadibrata. Upaya Pencegahan Anemia Gizi Pada Ibu Hamil. J. IImu Gizi 2, 118-124 (2011). 
5. Kementerian Kesehatan RI. Profil Kesehatan Indonesia. (2011).

6. Kementerian Kesehatan RI. InfoDatin Situasi Kesehatan Ibu 2014. (2014).

7. Dinas Kesehatan Provinsi Jawa Timur. Profil Kesehatan Provinsi Jawa Timur Tahun 2015. (2015).

8. Sumarmi, S., Puspitasari, N., Handajani, R. \& Wirjatmadi, B. Underweight as a Risk Factor for Iron Depletion and IronDeficient Erythropoiesis among Young Women in Rural Areas of East Java , Indonesia. Mal J Nutr (2016).

9. Sumarmi, S., Puspitasari, N., Mahmudiono, T. \& Megatsari, $\mathrm{H}$. Peningkatan Status Gizi Calon Pengantin Wanita pada Kegiatan Penyusunan Angka Kecukupan Gizi Keluarga. (2008).

10. Putri, S. I. \& Sumarmi, S. Perbandingan konsumsi zat gizi, status gizi, dan kadar hemoglobin pengantin wanita di wilayah pantai dan pertanian kabupaten probolinggo. Media Gizi Indones. 9, 7277 (2013).

11. Nurhidayati; Rohmah, D. S. I. Analisis Faktor Penyebab Terjadinya Anemia Pada Ibu Hamil Di Wilayah Kerja Puskesmas Tawangsari Kabupaten Sukoharjo. (Universitas Muhammadiyah Surakarta, 2013).

12. Kementerian Kesehatan RI. Pedoman Pemantauan Wilayah Setempat Kesehatan Ibu dan Anak. (2010).

13. Aditianti, Permanasari, Y. \& Julianti, E. D. Pendampingan Minum Tablet Tambah Darah (TTD) Dapat Meningkatkan Kepatuhan Konsumsi TTD Pada Ibu Hamil Anemia. Penelit. Gizi dan Makanan 38, 71-78 (2015).

14. Erwin, R. R., Machmud, R. \& Utama, B. I. Artikel Penelitian Hubungan Pengetahuan dan Sikap Ibu Hamil dengan Kepatuhan dalam Mengkonsumsi Tablet Besi di Wilayah Kerja Puskesmas Seberang Padang Tahun 2013. J. Kesehat. Andalas 6, 596601 (2017).

15. Kamidah. Faktor-Faktor Yang Mempengaruhi Kepatuhan Ibu Hamil Mengkonsumsi Tablet Fe Di Puskesmas Simo Boyolali. Gaster XII, (2015).

16. Mardiana. Faktor-Faktor yang
Berhubungan dengan Kepatuhan Ibu Hamil Mengkonsumsi Tablet Besi di Puskesmas Sako dan Puskesmas Multi Wahana Kota Palembang Tahun 2004. (Universitas Indonesia, 2004).

17. Swirya, H. J. Hubungan Kepatuhan Konsumsi Tablet Tambah Darah Dengan Status Anemia Ibu Hamil Di Desa Kotaraja Kecamatan Sikur Kab. Lombok Timur. Media Bina IIm. 7, (2013).

18. Dinas Kesehatan Kabupaten Probolinggo. Profil Kesehatan Kabupaten Probolinggo Tahun 2014. (2014).

19. Amirudin, W. Studi Kasus Kontrol Faktor Biomedis Terhadap Kejadian Anemia Ibu Hamil di Puskesmas Bantimurung Maron. J. Med. Nusant. 25, (2014).

20. Astriana, W. Kejadian Anemia pada Ibu Hamil Ditinjau dari Paritas dan Usia. 2, 123-130 (2017).

21. Anggraini, D. D., Purnomo, W. \& Trijanto, B. Effect of pregnant women's knowledge and therapy regimentation towards compliance in consuming iron ( Fe ) tablets and anemia degree in South Kediri Public Health Center year 2016. Maj. Obstet. Ginekol. 24, 61-63 (2016).

22. Rahmawati \& Subagio. Kepatuhan Konsumsi Tablet Besi Folat Pada Ibu Hamil Dan Faktor Yang Mempengaruhi. J. Nutr. Coll. 1, 55-62 (2012).

23. Nadhifah, T. H. Kepatuhan Ibu Hamil TM II Mengkonsumsi Tablet Fe Di Puskesmas Kalibawang, Kabupaten Kulon Progo, Yogyakarta Tahun 2014. (Sekolah Tinggi Ilmu Kesehatan Jederal Achmad Yani Yogyakarta, 2017).

24. Ramadhan, M. Hubungan Pengetahuan 1000 Hari Pertama Kehidupan Dan Dukungan Keluarga Dengan Kepatuhan Ibu Hamil Dalam Mengkonsumsi Tablet Fe. (Universitas Airlangga, 2017).

25. Sajith et al. Correlation of adherence to iron supplements and prevalence of anemia in antenatal women. Int $\mathrm{J}$ Reprod Contracept Obs. Gynecol 5, 3448-3452 (2015).

26. Anggraini, D. D. Faktor Yang Mempengaruhi Kepatuhan Mengkonsumsi Tablet Besi (Fe) Dan Anemia Pada Ibu Hamil Puskesmas Kota 
Wilayah Selatan Kota Kediri. (Universitas Airlangga, 2016).

27. Handayani, D; Dachlan, D. M; Salam, A. Faktor-Faktor Yang Mempengaruhi Tingkat Kepatuhan Ibu Multigravida Dalam Mengkonsumsi Tablet Fe Di Puskesmas Polanharjo, Klaten. J. KESMADASKA 5, (2014).

28. Hendrian, R. Faktor-Faktor Yang Berhubungan Dengan Perilaku Ibu Hamil Dalam Mengkonsumsi Tablet Besi di Puskesmas Kota Gede Kabupaten Kuningan. (Universitas Syarif Hidayatullah Jakarta, 2011).

29. Mandariska, C. Hubungan Kepatuhan Meminum Tablet Fe Terhadap Kejadian Anemia Pada Ibu Hamil Trimester III di Puskesmas Kalikajari Wonosobo. (Stikes 'Aisyiyah Yogyakarta, 2014).

30. Festy, P. Analisis Faktor Resiko Pada Kejadian Berat Badan Lahir Rendah Di Kabupaten Sumenep. Gaster 5, (2011).

31. Fuady \& Datten. Hubungan Pengetahuan Ibu Hamil Tentang Anemia Defisiensi Besi Terhadap Kepatuhan Mengkonsumsi Tablet Zat Besi. E-Journal FK USU 1, 1-5 (2013).

32. Rochyati, E. Studi Kualitatif Tingkat Kepatuhan Ibu Hamil Mengkonsumsi Zat
Besi di Wilayah Kerja Puskesmas Kampung Sawah Kabupaten Tangerang Tahun 2008. (Universitas Islam Negeri Syarif Hidayatullah Jakarta, 2008).

33. Sartika, M. N. . Hubungan Antara Pengetahuan Dan Sikap Tentang Anemia Dengan Keteraturan Mengkonsumsi Fe Pada Ibu Hamil Di BPS Sri Lumintu Surakarta. (Universitas Sebelas Maret, 2010).

34. Wiradnyani, L. A. A., Khusun, H. \& Achadi, E. L. Faktor-faktor yang berhubungan dengan kepatuhan ibu mengonsumsi tablet besi-folat selama kehamilan. J. Gizi dan Pangan 8, 63-70 (2013).

35. Puspitasari, Saryono \& Ramawati. Faktor-Faktor Yang Mempengaruhi Kepatuhan Ibu Hamil Dalam Mengkonsumsi Tablet Besi di Desa Sokaraja Tengah, Kecamatan Sokaraja, Kabupaten Banyumas. J. Keperawatan Soedirman 3, 25-31 (2008).

36. Sulistiyanti, A. Hubungan Tingkat Pengetahuan Ibu Hamil Tentang Anemia Dengan Kepatuhan Konsumsi Tablet Fe Di Wilayah Kerja Puskesmas Masaran I Sragen. J. Kebidanan dan IImu Kesehat. 2, 8-22 (2015). 